\title{
Record-breaking ozone loss in the Arctic winter 2010/2011: comparison with 1996/1997
}

\author{
J. Kuttippurath ${ }^{1}$, S. Godin-Beekmann ${ }^{1}$, F. Lefèvre ${ }^{1}$, G. Nikulin $^{2}$, M. L. Santee ${ }^{3}$, and L. Froidevaux ${ }^{3}$ \\ ${ }^{1}$ UPMC Université Paris 06, LATMOS-IPSL, CNRS/INSU, UMR8190, 75005 Paris, France \\ ${ }^{2}$ Swedish Meteorological Hydrological Institute, Kiruna, Sweden \\ ${ }^{3}$ JPL/NASA, California Institute of Technology, Pasadena, California, USA
}

Correspondence to: J. Kuttippurath (jayanarayanan.kuttippurath@latmos.ipsl.fr)

Received: 5 February 2012 - Published in Atmos. Chem. Phys. Discuss.: 6 March 2012

Revised: 25 July 2012 - Accepted: 27 July 2012 - Published: 6 August 2012

\begin{abstract}
We present a detailed discussion of the chemical and dynamical processes in the Arctic winters 1996/1997 and 2010/2011 with high resolution chemical transport model (CTM) simulations and space-based observations. In the Arctic winter 2010/2011, the lower stratospheric minimum temperatures were below $195 \mathrm{~K}$ for a record period of time, from December to mid-April, and a strong and stable vortex was present during that period. Simulations with the Mimosa-Chim CTM show that the chemical ozone loss started in early January and progressed slowly to 1 ppmv (parts per million by volume) by late February. The loss intensified by early March and reached a record maximum of $\sim 2.4 \mathrm{ppmv}$ in the late March-early April period over a broad altitude range of $450-550 \mathrm{~K}$. This coincides with elevated ozone loss rates of $2-4 \mathrm{ppbv} \mathrm{sh}^{-1}$ (parts per billion by volume/sunlit hour) and a contribution of about 30-55\% and $30-35 \%$ from the $\mathrm{ClO}-\mathrm{ClO}$ and $\mathrm{ClO}-\mathrm{BrO}$ cycles, respectively, in late February and March. In addition, a contribution of $30-50 \%$ from the $\mathrm{HO}_{\mathrm{x}}$ cycle is also estimated in April. We also estimate a loss of about 0.7-1.2 ppmv contributed $(75 \%)$ by the $\mathrm{NO}_{\mathrm{x}}$ cycle at $550-700 \mathrm{~K}$. The ozone loss estimated in the partial column range of $350-550 \mathrm{~K}$ exhibits a record value of $\sim 148$ DU (Dobson Unit). This is the largest ozone loss ever estimated in the Arctic and is consistent with the remarkable chlorine activation and strong denitrification (40-50\%) during the winter, as the modeled $\mathrm{ClO}$ shows $\sim 1.8$ ppbv in early January and $\sim 1$ ppbv in March at $450-550 \mathrm{~K}$. These model results are in excellent agreement with those found from the Aura Microwave Limb Sounder observations. Our analyses also show that the ozone loss in 2010/2011 is close to that found in some Antarctic winters,
\end{abstract}

for the first time in the observed history. Though the winter 1996/1997 was also very cold in March-April, the temperatures were higher in December-February, and, therefore, chlorine activation was moderate and ozone loss was average with about $1.2 \mathrm{ppmv}$ at $475-550 \mathrm{~K}$ or $42 \mathrm{DU}$ at $350-550 \mathrm{~K}$, as diagnosed from the model simulations and measurements.

\section{Introduction}

Chemical ozone loss in the Arctic stratosphere has been observed since 1989. Since then, cold winters are prone to large chemical ozone loss due to the still high amounts of ozone depleting substances in the atmosphere (Rex et al., 2004). However, because of large planetary wave activity, the polar vortex breaks up or dissipates early in most Arctic winters (WMO, 2011; Harris et al., 2010; Kuttippurath et al., 2010b; Manney et al., 2003). Therefore, the vortex persistence has been comparatively shorter and the associated ozone loss smaller in the Arctic as compared to the Antarctic (WMO, 2011; Solomon et al., 2007). The longest vortex persistence in the Arctic was found in 1996/1997, in which the wave activity was considerably suppressed, and therefore the vortex was sustained until early May (Lefèvre et al., 1998; Coy et al., 1997). Nevertheless, the ozone loss in 1996/1997 was lower than that of other cold winters such as 1994/1995, $1999 / 2000$, and 2004/2005 due to relatively higher temperatures in December-February 1996/1997, when chlorine activation plays a key role in determining the magnitude of ozone loss (Manney et al., 2003; Santee et al., 1997). In contrast, very low temperatures were observed in March-April due

Published by Copernicus Publications on behalf of the European Geosciences Union. 
to a high tropopause associated with a tropospheric blocking during the 1996/1997 Arctic winter (Coy et al., 1997). A similar evolution in temperature and vortex persistence was also observed in spring 2011 (Hurwitz et al., 2011; Manney et al., 2011), during which the stratospheric halogen loading was very similar to that in $1996 / 1997$. Note that long persistence of a cold vortex is a necessary requirement for the sustained ozone loss. Studies have already shown prolonged appearance of very low temperatures and exceptional ozone loss in 2010/2011 (Balis et al., 2011; Manney et al., 2011; Sinnhuber et al., 2011). Persistence of very low temperatures and strong vortices for a record period of time, and very late final warmings were the common features of the Arctic winters 1996/1997 and 2010/2011. The vortex in 1996/1997 was even stronger and the final warming was later than in 2010/2011. However, the chemical processing and ozone loss were different in these winters. Therefore, the situations in both winters merit a close examination to diagnose the similarities and differences between the polar processing of the winters and to find possible reasons for them. The winters are analyzed with high resolution chemical transport model simulations and satellite measurements to further elucidate the ozone loss processes.

This article is arranged in the following order: Sect. 2 describes the data and methods, including the model simulations, the MLS measurements and European Centre for Medium-Range Weather Forecasts (ECMWF) data. The results from the study are discussed in Sect. 3, in which meteorology (Sect. 3.1) and ozone loss (Sect. 3.2) during the winters 1996/1997 and 2010/2011 are presented. A detailed characterization of the dynamics of both winters is presented in this part with temperature and zonal wind, and heat flux and wave amplitude calculations. In addition, the time evolution of the polar vortex is demonstrated with potential vorticity (PV) maps. Apart from the ozone loss calculations by the passive method, the ozone loss and production rates, and the contribution of various chemical cycles to the ozone loss are given in Sect. 3.3 to help the interpretation of the derived ozone loss. The vertical features of ozone loss are compared to the partial column ozone loss estimations from both simulations and measurements and are discussed in Sect. 3.4. Sect. 3.5 compares the ozone loss estimated in this study with other available ones. The atypical ozone loss that occurred in the Arctic winter 2010/2011 is compared to the Antarctic ozone loss in Sect. 4. The primary findings of this study are summarized in Sect. 5.

\section{Data and method}

We use the high resolution chemical transport model (CTM) Mimosa-Chim for this study (e.g. Kuttippurath et al., 2010b; Tripathi et al., 2006). The model has $1 \times 1^{\circ}$ horizontal resolution in the spatial domain of $10^{\circ} \mathrm{S}-90^{\circ} \mathrm{N}$ with 25 isentropical vertical levels between $350 \mathrm{~K}$ and $950 \mathrm{~K}$, with $5 \mathrm{~K}$ resolution between $425 \mathrm{~K}$ and $550 \mathrm{~K}$ to study the ozone depletion layers closely. The ECMWF analyses are used to force the model runs, and the model uses the MIDRAD radiation scheme (Shine, 1987). The chemical fields of the model runs are initialized from the 3-D CTM REPROBUS output (Lefèvre et al., 1998). The kinetic data are taken from Sander et al. (2006), but the $\mathrm{Cl}_{2} \mathrm{O}_{2}$ cross-sections are from Burkholder et al. (1990), with a log-linear extrapolation up to $450 \mathrm{~nm}$ as suggested by Stimpfle et al. (2004). Although there are new measurements for $\mathrm{Cl}_{2} \mathrm{O}_{2}$ (Papanastasiou et al., 2009), the differences in the simulated ozone loss among various sensitivity runs are very small $(2 \%)$ (Kuttippurath et al., 2010b). The model has detailed polar stratospheric cloud (PSC) and sedimentation schemes. As we use the same model and run procedures, further details of the model runs can be found in Kuttippurath et al. (2010b). For the winters considered here, the model was run from 1 December to 30 April. We use the passive tracer method (WMO, 2007 and references therein) to derive ozone depletion, for which the ozone $\left(\mathrm{O}_{3}\right)$ and passive tracer are initialized together in the beginning of each simulation, and then the ozone loss is estimated as Mimosa-Chim $\mathrm{O}_{3}$ or $\mathrm{MLS}_{3}$ minus the passive tracer.

To compare with the simulations, we use measurements of $\mathrm{O}_{3}$ and chlorine monoxide $(\mathrm{ClO})$ from the Upper Atmosphere Research Satellite (UARS) Microwave Limb Sounder (MLS) version (v)5 for the winter 1996/1997 and the Aura MLS v3.3 for the winter 2010/2011. The UARS MLS O profiles have a vertical range of about $15-60 \mathrm{~km}$ and a vertical resolution of $\sim 3-4 \mathrm{~km}$. The uncertainty of a typical $\mathrm{O}_{3}$ measurement is $6-15 \%$ over $16-60 \mathrm{~km}$. The Aura MLS $\mathrm{O}_{3}$ measurements have a vertical range of about $12-73 \mathrm{~km}$ with a vertical resolution of $2.5-3 \mathrm{~km}$ and an uncertainty of $5-10 \%$ between $68 \mathrm{hPa}$ and $0.2 \mathrm{hPa}$. The vertical range of UARS MLS ClO profiles is $100-1 \mathrm{hPa}$, with a vertical resolution of $4-5 \mathrm{~km}$ and an uncertainty of $20 \%$ at $46 \mathrm{hPa}$, whereas the Aura MLS $\mathrm{ClO}$ has a vertical resolution of 3$3.5 \mathrm{~km}$ and a vertical range of $100-0.1 \mathrm{hPa}$. The uncertainty of Aura MLS ClO retrievals is about 10-20\%, depending on altitude. In order to screen the UARS MLS data we have used the guidelines provided by Livesey et al. (2003), with only profiles with positive precision values, Quality values $(=4)$, and "MMAF_STAT" flags with "G", " $t$ ", or "T" being considered. We have also subtracted altitude dependent known biases identified in the UARS $\mathrm{ClO}$ profiles prior to their interpolation to specific potential temperature levels. The selection of Aura MLS profiles are based on their Convergence, Quality, Status, and Precision values as recommend by Livesey et al. (2011) for each molecule. In addition, latitude-dependent biases at 146, 100 and $68 \mathrm{hPa}$ are subtracted from the $\mathrm{ClO}$ profiles before their vertical interpolation. Further details about the data and data screening procedures can be found in Livesey et al. (2003) for UARS MLS and Froidevaux et al. (2008), Santee et al. (2008), and Livesey et al. (2011) for Aura MLS. 


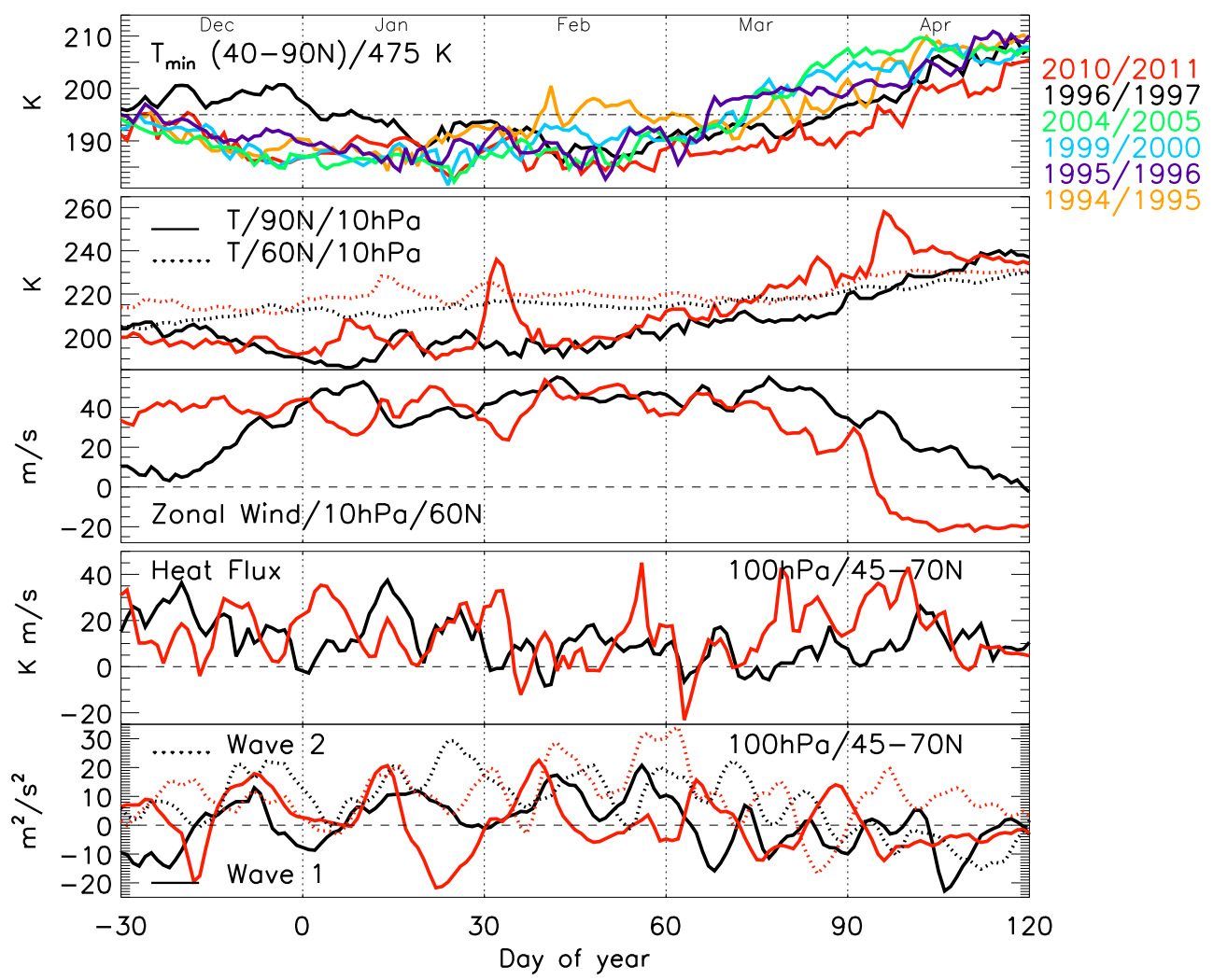

Fig. 1. Temporal evolution of minimum temperature at $475 \mathrm{~K}$ (top plot), temperature at $60^{\circ} \mathrm{N}$ and $90^{\circ} \mathrm{N}$ at $10 \mathrm{hPa}$ (second plot from the top), zonal wind at $60^{\circ} \mathrm{N} / 10 \mathrm{hPa}$ (third plot from the top), heat flux (fourth plot from the top), and planetary wave amplitudes (bottom) for the Arctic winters 1996/1997 (black) and 2010/2011 (red). The heat flux and wave amplitudes are averaged between $45^{\circ} \mathrm{N}$ and $70^{\circ} \mathrm{N}$ at $100 \mathrm{hPa}$. The minimum temperatures during the cold Arctic winters 1994/1995 (yellow), 1995/1996 (violet), 1999/2000 (blue) and 2004/2005 (green) are also shown. The dash-dotted line represents $195 \mathrm{~K}$ temperature, the dashed lines mark the zero-wind line, zero heat flux or zero wave amplitude in the respective plots, and dotted vertical lines differentiate the approximate boundaries of each month.

We use the ECMWF operational meteorological analyses to calculate the minimum temperature, PV, heat flux, planetary waves, and vortex edge. The ECMWF data archived at the Norwegian Institute for Air Research (NILU) data base are used in this study. These analyses have a horizontal resolution of $2.5 \times 2.5^{\circ}$ and are available at $1000,700,500,300$, $200,150,100,70,50,30$ and $10 \mathrm{hPa}$ pressure levels (e.g. Woods, 2006).

\section{Results and discussion}

\subsection{Synoptic evolution of the winters}

Figure 1 shows the minimum temperature extracted north of $40^{\circ} \mathrm{N}$, zonal wind, heat flux and the wave 1 and 2 calculated from geopotential fields for the Arctic winters 1996/1997 and 2010/2011. In 1996/1997, the minimum temperatures show values above and below $195 \mathrm{~K}$ in December and JanuaryMarch, respectively. On the other hand, temperatures below $195 \mathrm{~K}$ from December through early April are observed in 2010/2011 (Manney et al., 2011). So the minimum temper- ature in 2010/2011 is consistently lower than in 1996/1997 throughout the winter by about $2-10 \mathrm{~K}$. As compared to other cold winters in the Arctic, the temperature in 2010/2011 is similar until mid-February, but about $10-20 \mathrm{~K}$ lower than that of other winters in March-April, indicating the longest period of low temperatures in the last two decades (Manney et al., 2011; Sinnhuber et al., 2011). The temperature in $1996 / 1997$ is also lower than that in 1994/1995, 1999/2000 and 2004/2005 from mid-March to April, but is about 10 $20 \mathrm{~K}$ higher in December-February than all other winters. It should be recalled that these analyses hold for $475 \mathrm{~K}$ only. The winters 1999/2000, 2004/2005, and 2010/2011 exhibit the lowest minimum temperature of about $182 \mathrm{~K}$ around 20 January.

To diagnose sudden stratospheric warmings, the temperature at $60^{\circ} \mathrm{N} / 10 \mathrm{hPa}$ and $90^{\circ} \mathrm{N} / 10 \mathrm{hPa}$ and zonal winds at $60^{\circ} \mathrm{N} / 10 \mathrm{hPa}$ are analyzed. In 1996/1997, there were no warmings and the westerlies were strong with a speed of $\sim 40 \mathrm{~m} \mathrm{~s}^{-1}$ in January-April, with the final warming unusually late in early May. In contrast, two minor warmings with a magnitude of about $10 \mathrm{~K}$ and $40 \mathrm{~K}$ at $90^{\circ} \mathrm{N} / 10 \mathrm{hPa}$ in early 


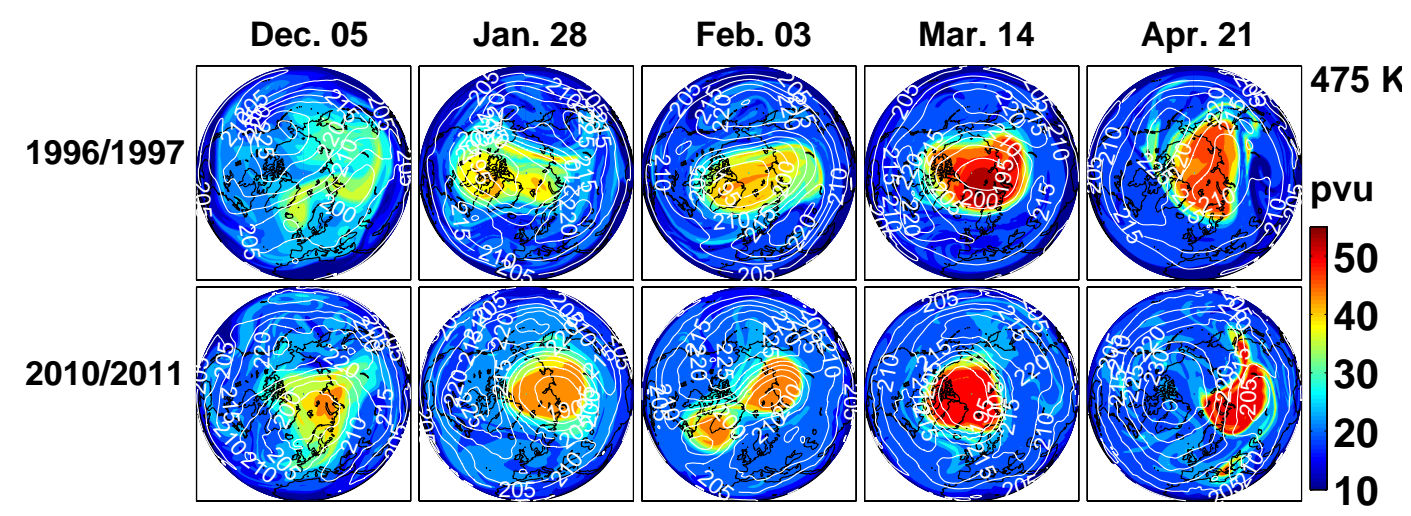

Fig. 2. Temporal evolution of the polar vortex during selected days of the Arctic winters 1996/1997 (upper panel) and $2010 / 2011$ (lower panel) at $475 \mathrm{~K}$ potential temperature level. The days are selected by analyzing the complete record of the winter to fairly represent the temporal evolution. The overlaid white contours are temperature in Kelvin. The blue/red colors show relatively low/high potential vorticity units (pvu), where 1 pvu is $10^{-6} \mathrm{~km}^{2} \mathrm{~kg}^{-1} \mathrm{~s}^{-1}$.

January and early February, respectively, were observed in 2010/2011. These warmings lasted for a week, and were due to wave 1 and wave 2 amplifications, with zonal mean heat fluxes ( $v^{\prime} T^{\prime}$ at $45-70^{\circ} \mathrm{N} / 100 \mathrm{hPa}$ ) of about $34 \mathrm{~K} \mathrm{~m} \mathrm{~s}^{-1}$. Nevertheless, strong westerlies with a speed of $\sim 40 \mathrm{~m} \mathrm{~s}^{-1}$ were present from December to the end of March in 2010/2011. The temperatures began to increase by the second week of April and the winds turned to easterly, indicating the final warming, which was about two weeks earlier than in 1996/1997. The heat flux, Eliassen-Palm (EP) divergence, and EP flux of the waves 1 and 2 (not shown) show very small or near zero values in February-early April in both winters. This implies that there was no significant wave activity to warm the stratosphere up, and hence, the temperature stayed cold and winds remained westerly to sustain a stable vortex during the period. However, the heat flux in FebruaryApril and wave amplitudes in March-April show comparatively smaller amplitude in 1996/1997, indicating very weak wave driving during the winter. Therefore, prolonged persistence of lower temperatures, larger zonal wind amplitudes, and hence, an exceptionally late final warming are observed in the Arctic winter 1996/1997. Further details about the dynamical processes of both winters can be found in Hurwitz et al. (2011).

Figure 2 shows PV maps at $475 \mathrm{~K}$ on selected days of both winters. In 1996/1997 (top panel), the vortex was relatively large, stable and pole-centered for most days until late April. In December the vortex was undisturbed, but a minor warming occurred in early January. The vortex was unusually strong in February through mid-April, during which the vortex was mostly pole-centered and large in size. In contrast, in 2010/2011 (bottom panel), the vortex formed in early December with considerable size. Though the minor warming moved the vortex slightly off the pole in January, the vortex was still strong with $\mathrm{PV}$ values of $\sim 50$ pvu (PV units; 1 pvu is $10^{-6} \mathrm{Km}^{2} \mathrm{~kg}^{-1} \mathrm{~s}^{-1}$ ). The vortex stayed pole-centered again until the minor warming in early February, during which the vortex nearly split into two parts. Since the warming was short and the westerlies were strong, the vortex merged and regained its strength to form a large pole-centered one after a few days and stayed intact until late April 2011. Note that the vortex was still significantly smaller than that of other cold Arctic winters in February-April, including the winter 1996/1997 as shown by the PV maps in Fig. 2 and mentioned by Manney et al. (2011). In April, the temperatures began to increase and westerlies started to diminish, and the vortex tilted off the pole and, then stayed mostly in the midlatitudes until the final warming in late April. The vortex evolution was similar at most altitudes between $450 \mathrm{~K}$ and $850 \mathrm{~K}$, but the vortex dissipation was observed a few days earlier at $850 \mathrm{~K}$ in both winters.

\subsection{PSCs, chlorine activation and ozone loss}

\subsubsection{Winter 1996/1997}

Figure 3 shows the potential PSC areas, and the vortexaveraged Mimosa-Chim simulations of $\mathrm{ClO}, \mathrm{O}_{3}$, and ozone loss for the Arctic winter 1996/1997. The ClO data are filtered with respect to a criterion of 12:00 UT and solar zenith angle less than $89^{\circ}$. In this study the area of PSCs ( $\left.A_{\mathrm{PSC}}\right)$ is considered as the area where temperatures are less than the Nitric Acid Tri-hydrate (NAT) threshold, $T_{\mathrm{NAT}}$. The $T_{\mathrm{NAT}}$ estimation is done by applying the scheme of Hanson and Mauersberger (1988) using the ECMWF temperature and pressure analyses, with 4.5 ppmv (parts per million by volume) of $\mathrm{H}_{2} \mathrm{O}$ and $\mathrm{HNO}_{3}$ climatology (Rex et al., 2004; Kuttippurath et al., 2010b).

As the temperatures are above $195 \mathrm{~K}$, no PSCs are found in December. In January, PSCs with areas of $\sim 0.7 \times 10^{7} \mathrm{~km}^{2}$ are estimated at 500-600 K. Large areas of PSCs with a maximum of about $1.3 \times 10^{7} \mathrm{~km}^{2}$ are found at $400-550 \mathrm{~K}$ until mid-March and there were no PSCs afterwards, consistent 


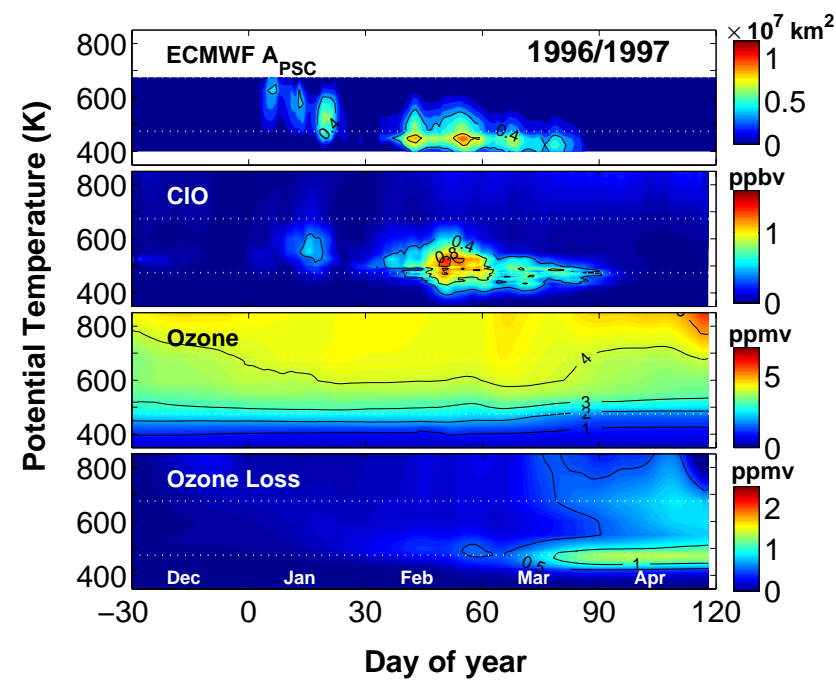

Fig. 3. Temporal evolution of the vertical distribution of potential PSC areas (top) and Mimosa-Chim simulations of $\mathrm{ClO}$ (second plot from the top), $\mathrm{O}_{3}$ (third plot from the top), and ozone loss (bottom) inside the vortex for the Arctic winter 1996/1997. The ClO profiles are selected at $12 \mathrm{UT}$ and solar zenith angles below $89^{\circ}$. The white dotted lines represent $475 \mathrm{~K}$ and $675 \mathrm{~K}$. The blue/red colors show relatively low/high values of PSC areas or mixing ratios of $\mathrm{ClO}$, $\mathrm{O}_{3}$, and ozone loss.

with the temperatures during the period. So the chlorine activation was moderate, as indicated by the $\mathrm{ClO}$ mixing ratios of $\sim 0.7 \mathrm{ppbv}$ (parts per billion by volume) in mid-January, about $1-1.7 \mathrm{ppbv}$ in mid-February and about $0.5 \mathrm{ppbv}$ in March around $475 \mathrm{~K}$. Since the vortex was symmetric and pole-centered, there were no changes in $\mathrm{O}_{3}$ distributions at most altitudes until late February, but a reduction of 1$1.3 \mathrm{ppmv}$ was found thereafter in the lower stratosphere in the sunlit parts of the vortex. This change in $\mathrm{O}_{3}$ is evident when following the $3 \mathrm{ppmv}$ and 4 ppmv $\mathrm{O}_{3}$ isopleths. The corresponding ozone loss is about $0.6 \mathrm{ppmv}$ in late February and $1.2 \mathrm{ppmv}$ in late March-April around $475 \mathrm{~K}$. There is also a significant loss of $0.4-0.7$ ppmv, by $\mathrm{NO}_{\mathrm{x}}$ catalytic chemistry, at altitudes above $550 \mathrm{~K}$ up to $700 \mathrm{~K}$ in April. Since the denitrification in the winter 1996/1997 was studied extensively (e.g. Kondo et al., 2000; Santee et al., 1999) and was not severe as in other cold Arctic winters (e.g. Kleinböhl et al., 2005), we have excluded discussions on denitrification in this winter.

Figure 4 compares the $\mathrm{ClO}, \mathrm{O}_{3}$, and ozone loss simulations with those from the UARS MLS measurements. Here data are selected with respect to the MLS sampling points inside the vortex and hence, these are slightly different from the vortex averages shown in Fig. 3. The model results are in reasonable agreement with the observations. The simulated $\mathrm{ClO}$ is slightly lower (e.g. Santee et al., 1997) and $\mathrm{O}_{3}$ is a little higher, and thus, the simulated ozone loss is about $0.1-$ 0.2 ppmv lower than in the observations at $425-550$ K. Still the measurements also show a peak loss of about 1.2 ppmv by late April. In addition, our results are in good agreement with those of Manney et al. $(2003,1997)$ and Knudsen et al. (1998), who estimate a peak ozone loss of about $1.2 \mathrm{ppmv}$ at $465 \mathrm{~K}$ and $1.24 \mathrm{ppmv}$ at $475 \mathrm{~K}$ by late March from UARS MLS and ozonesonde measurements, respectively. The SLIMCAT model also calculates a similar ozone loss maximum of about $1.1 \mathrm{ppmv}$ at $475 \mathrm{~K}$ in late March (Hanson and Chipperfield, 1999).

\subsubsection{Winter 2010/2011}

Figure 5 presents the modeled and measured $\mathrm{ClO}, \mathrm{HNO}_{3}$, $\mathrm{O}_{3}$, and ozone loss at the Aura MLS sampling locations inside the vortex, together with the area of PSCs, for the winter 2010/2011. Large areas of PSCs with maximum values of about $1.1 \times 10^{7} \mathrm{~km}^{2}$ are estimated from mid-December to late March. Note that the $A_{\text {PSC }}$ in 2010/2011 is systematically larger than that in $1996 / 1997$ both with time and altitude. This suggests that the winter 2010/2011 had an unusually long period of PSC appearance in a wide vertical extent between $400 \mathrm{~K}$ and $600 \mathrm{~K}$ compared to any other Arctic winter (Manney et al., 2011; Kuttippurath et al., 2010b).

Consistent with the $A_{\mathrm{PSC}}$, about $0.5-0.7 \mathrm{ppbv}$ of $\mathrm{ClO}$ in December and 1-1.8 ppbv of $\mathrm{ClO}$ in January-March at 450 $600 \mathrm{~K}$ are simulated. The $\mathrm{ClO}$ simulations show the record maximum of about $1.8 \mathrm{ppbv}$ in mid-January around 475$700 \mathrm{~K}$. Unlike in other Arctic winters (WMO, 2011; Kuttippurath et al., 2010b), the model calculates large $\mathrm{ClO}$ values in March at 450-600 K, pointing to an unusually high chlorine activation for an extended period of time. Furthermore, the $\mathrm{HNO}_{3}$ profiles depict strong denitrification (about 40-50 \%) as they register about $15 \mathrm{ppbv}$ in December, but are denitrified to 5-8 ppbv in January-March in the lower stratosphere, in agreement with the analyses presented in Manney et al. (2011) and Sinnhuber et al. (2011). In accordance with the high chlorine activation, substantial reduction in $\mathrm{O}_{3}$ is modeled from late January onwards. The ozone loss started in the sunlit part of the vortex when it moved to the midlatitudes during the minor warming in early February, with values of about $0.5 \mathrm{ppmv}$ around $550 \mathrm{~K}$. The loss increased to $1.2 \mathrm{ppmv}$ at $475 \mathrm{~K}$ by late February and then rapidly reached the maximum loss of 2-2.4 ppmv by the end of March in $450-550 \mathrm{~K}$. Since most Arctic winters show the peak loss in a narrow vertical region, this case in 2010/2011 stands in contrast with those. A significant loss of around $1 \mathrm{ppmv}$ is also simulated due to the $\mathrm{NO}_{\mathrm{x}}$ chemistry above $550 \mathrm{~K}$ in February-March. Such large ozone loss at higher altitudes is atypical in the Arctic winters (e.g. Kuttippurath et al., 2010b; Rex et al., 2004; Manney et al., 2003).

The model simulations also feature the same ozone loss patterns as the Aura MLS measurements, such as the timing of the onset of loss, the altitude range of loss, and the altitude and timing of the maximum loss and, therefore, exhibit excellent agreement with the observations. Nevertheless, the 


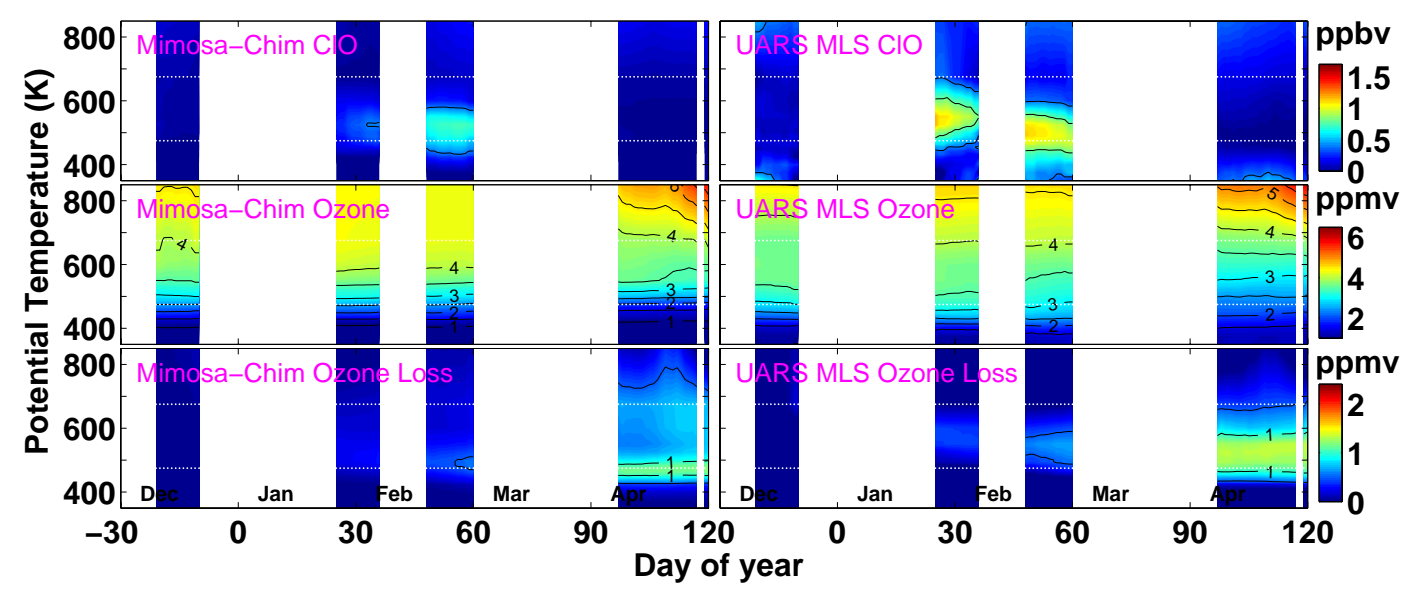

Fig. 4. Temporal evolution of the vertical distribution of $\mathrm{ClO}$ (top panel), $\mathrm{O}_{3}$ (middle panel), and ozone loss (bottom panel) from MimosaChim and UARS MLS for the Arctic winter 1996/1997. The model fields are sampled at the location of MLS observations for each measurement inside the vortex and then averaged for the corresponding day. Both data are smoothed for seven days. The Model and MLS ClO coincident profiles are selected for solar zenith angles $<89^{\circ}$ and local time between $10 \mathrm{~h}$ and $16 \mathrm{~h}$. The MLS ClO profiles are bias corrected (see text). The white dotted lines represent $475 \mathrm{~K}$ and $675 \mathrm{~K}$. The blue/red colors show relatively low/high mixing ratios of $\mathrm{ClO}, \mathrm{O}_{3}$, or ozone loss. The contour interval is $0.5 \mathrm{ppmv}$ of $\mathrm{O}_{3}$ or $0.5 \mathrm{ppbv}$ of $\mathrm{ClO}$.

simulated ozone loss slightly overestimates the Aura MLS observations, as the peak loss is about $0.1-0.2$ ppmv lower than that of the observations. This bias is due to the comparatively higher $\mathrm{ClO}$ and lower $\mathrm{O}_{3}$ in the model. The maximum ozone loss found in this study is in good agreement with that estimated from the Aura MLS and Michelson Interferometer for Passive Atmospheric Sounding (MIPAS) observations, about 2.3-2.5 ppmv, by Manney et al. (2011) and Sinnhuber et al. (2011), respectively.

To check the sensitivity to PSCs, we have simulated ozone loss without considering NAT PSCs in the model (e.g. Pitts et al., 2007; WMO, 2011). The test run results give (not shown) a maximum ozone loss of about 1.8 ppmv in 450 $550 \mathrm{~K}$ when the model considers only the liquid and ice PSCs. As compared to the control run with NAT (plus liquid and ice PSCs) PSCs, the model simulates about $10 \%$ less ozone loss at $475 \mathrm{~K}$, but nearly the same ozone loss (about $17-19 \%$ ) for both runs at $675 \mathrm{~K}$. It confirms that the effect of NAT PSCs on the ozone loss simulations is quite large in the lower stratosphere. This experiment suggests that the contribution of denitrification to the ozone loss of $2.4 \mathrm{ppmv}$ from the control run is about $25 \%$ and is the largest among the Arctic winters (WMO, 2007). Note that this ozone loss (1.8 ppmv simulated with liquid/ice PSCs only) is still larger than that observed in any other Arctic winter, as the previous maximum of 1.6 ppmv was in 2004/2005 (Manney et al., 2011; WMO, 2011; Kuttippurath et al., 2010b).

\subsection{Ozone loss rates and production rates}

Figure 6a shows the ozone loss and production rates simulated at $475 \mathrm{~K}$ and $675 \mathrm{~K}$ for selected Arctic winters, including 1996/1997 and 2010/2011. In 1996/1997, the ozone loss was moderate and, therefore, loss rates of about 2 $3 \mathrm{ppbv} \mathrm{sh}^{-1}$ (parts per billion by volume/sunlit hours) are simulated from mid-February to mid-March at $475 \mathrm{~K}$, as a result of significant $\mathrm{ClO}$ enhancements in this time period. In 2010/2011, the model simulates an atypical loss rate of 2$4 \mathrm{ppbv} \mathrm{sh}^{-1}$ in March and early April. It should be noted that there are high loss rates in December and January 2010/2011 in the lower stratosphere at $475 \mathrm{~K}$ as a result of enhancement in $\mathrm{ClO}$, as also shown by Manney et al. (2011), which is important for the cumulative ozone loss of the winter. As expected, there is no $\mathrm{O}_{3}$ production in the lower stratosphere. In the middle stratosphere, at $675 \mathrm{~K}$ (Fig. 6a), a loss rate of 2-5 ppbv sh ${ }^{-1}$ is simulated in March-April in 1996/1997. On the other hand, in 2010/2011, large loss rates of about 4$5 \mathrm{ppbv} \mathrm{sh}^{-1}$ in January and $13 \mathrm{ppbvsh}^{-1}$ in mid-April are calculated by the model. No significant $\mathrm{O}_{3}$ production was found until mid-March in both winters, but episodically high production rates of about 5-7 $\mathrm{ppbv} \mathrm{sh}^{-1}$ in 1996/1997 and $10-12 \mathrm{ppbv} \mathrm{sh}^{-1}$ in 2010/2011 are estimated thereafter.

In most Arctic winters, as depicted in the figure, the loss rates show a maximum of about $3-5 \mathrm{ppbv} \mathrm{sh}^{-1}$ in midJanuary, mid-February and late February/early March in warm (2008/2009), moderately cold (2007/2008) and cold (2004/2005) winters, respectively, and then suddenly drop to zero loss rate as there is no loss thereafter in the lower stratosphere, at $475 \mathrm{~K}$. Though the loss rates are larger in late February-early March at higher altitudes (e.g. $675 \mathrm{~K}$ ), $\mathrm{O}_{3}$ production rates outweigh these high loss rates even in cold winters. In contrast, there are higher ozone loss rates at $475 \mathrm{~K}$ in March and early April and relatively lower $\mathrm{O}_{3}$ production rates at $675 \mathrm{~K}$ in February through mid-March in 2010/2011 than in other years. This indicates that the winter 


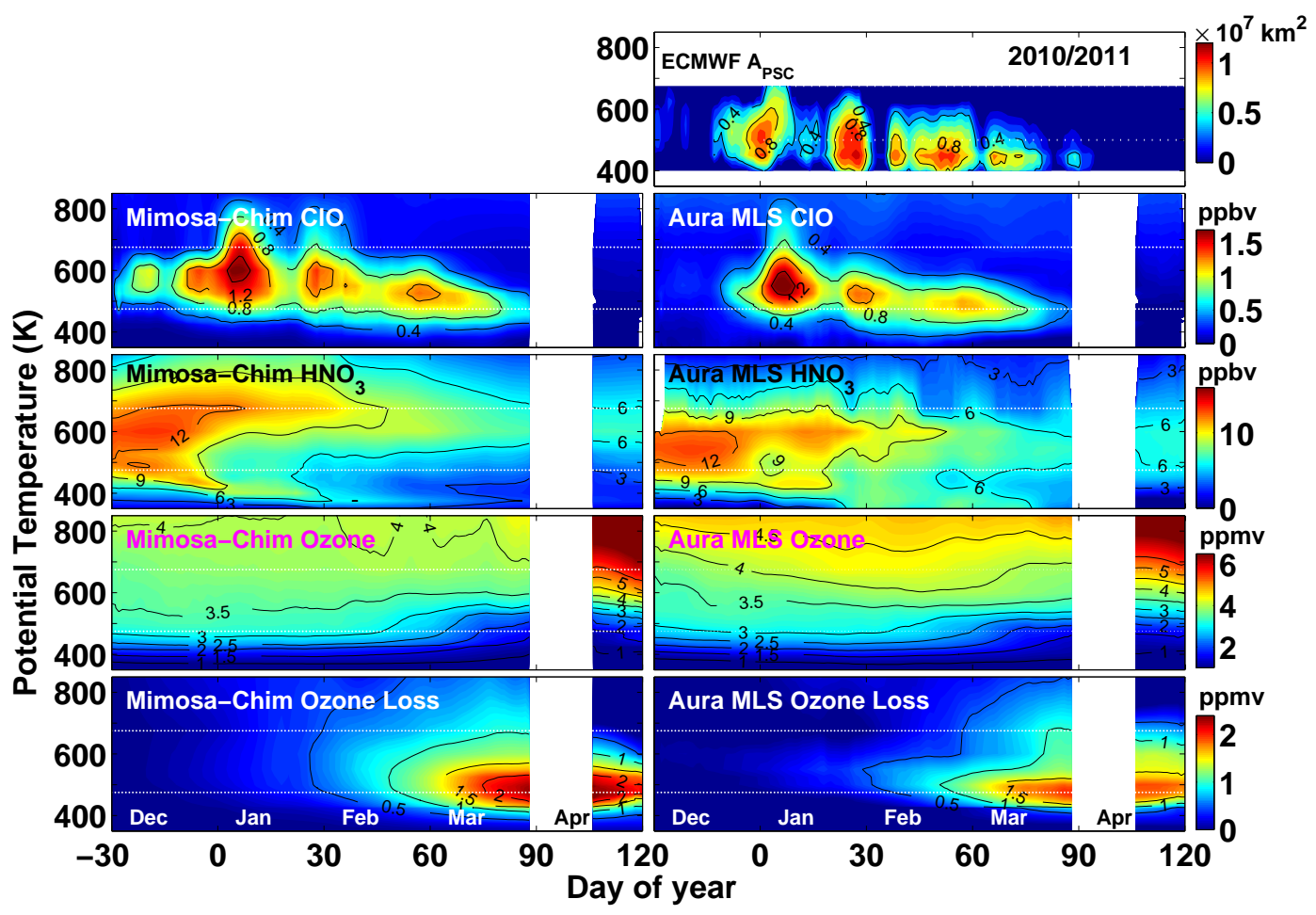

Fig. 5. Temporal evolution of the vertical distribution of $\mathrm{ClO}$ (second panel from the top), $\mathrm{HNO}_{3}$ (third panel from the top), $\mathrm{O}_{3}$ (fourth panel from the top), and ozone loss (bottom panel) from Mimosa-Chim and Aura MLS for the Arctic winter 2010/2011. The model fields are sampled at the location of MLS observations for each measurement inside the vortex and then averaged for the corresponding day. Both data are smoothed for seven days. The Model and MLS ClO coincident profiles are selected for solar zenith angles $<89^{\circ}$ and local time between $10 \mathrm{~h}$ and $16 \mathrm{~h}$. The MLS ClO profiles are bias corrected (see text). The $A_{\mathrm{PSC}}$ computed from the ECMWF operational analyses is also shown (top panel). The white dotted lines represent $475 \mathrm{~K}$ and $675 \mathrm{~K}$. The blue/red colors show relatively low/high values of PSC areas or mixing ratios of $\mathrm{ClO}, \mathrm{HNO}_{3}, \mathrm{O}_{3}$, and ozone loss.

2010/2011 was unique in terms of the record ozone loss rates in the lower stratosphere in the March-April period.

We have also evaluated the contribution of various chemical cycles to the ozone loss in the lower and middle stratosphere, as done by Kuttippurath et al. (2010b); results are shown in Fig. 6b. The general features and contributions from various chemical cycles in the lower and middle stratosphere are consistent with those of previous studies (Kuttippurath et al., 2010b; Vogel et al., 2008; Butz et al., 2007; Grooß et al., 2005; Hanson and Chipperfield, 1999; Woyke et al., 1999). However, in February-March 2011, our analyses show exceptional contributions from the $\mathrm{ClO}-\mathrm{ClO}$ (30$55 \%)$ and $\mathrm{BrO}-\mathrm{ClO}(30-35 \%)$ cycles in terms of absolute values in the lower stratosphere at $475 \mathrm{~K}$ (although the relative contributions from the various cycles look similar in both winters). The larger contributions of the halogen cycles in 2010/2011 are consistent with the prolonged appearance and large amounts of $\mathrm{ClO}$ during that period. In April 2011, a remarkable contribution from the $\mathrm{HO}_{\mathrm{x}}$ cycle $(30-$ $50 \%$ ) is also calculated in the lower stratosphere. This is linked to relatively higher values of $\mathrm{H}_{2} \mathrm{O}$ and $\mathrm{HNO}_{3}$, the sources of $\mathrm{HO}_{\mathrm{x}}$ in spring. In March-April 2011, the model simulates comparatively higher abundances of $\mathrm{NO}_{\mathrm{x}}$ at altitudes above $550 \mathrm{~K}$ (see Supplement figure), and hence this cycle dominates (with a 30-70\% contribution) the ozone loss there (Fig. 6b). The large contributions from these cycles in February-April are consistent with the large loss and loss rates during the period. The contributions of various chemical cycles during the winter 2010/2011 thus stand in contrast to those in other Arctic winters (e.g. Kuttippurath et al., 2010b; Hanson and Chipperfield, 1999), as that winter exhibited stronger and more prolonged (February to April) chemical $\mathrm{O}_{3}$ destruction in comparison to other Arctic winters. Although the relative chemical cycle contributions (see Fig. 6b) in 1996/1997 are comparable to those in 2010/2011, these contributions from all cycles in absolute terms are proportional to the ozone losses that occurred in the respective winters (Kuttippurath et al., 2010b; Butz et al., 2007; Woyke et al., 1999). Further discussions on the contribution of various cycles in the Arctic winter 1996/1997 can be found in Hanson and Chipperfield (1999). It should be borne in mind that the rate limiting step of these chemical cycles is the combination of $\mathrm{O}$-atom with the specific molecule (e.g. $\mathrm{O}+\mathrm{NO}_{2}$ for $\mathrm{NO}_{\mathrm{x}}$ and $\mathrm{O}+\mathrm{HO}_{2}$ for $\mathrm{HO}_{\mathrm{x}}$ ). Therefore, the efficiency and 


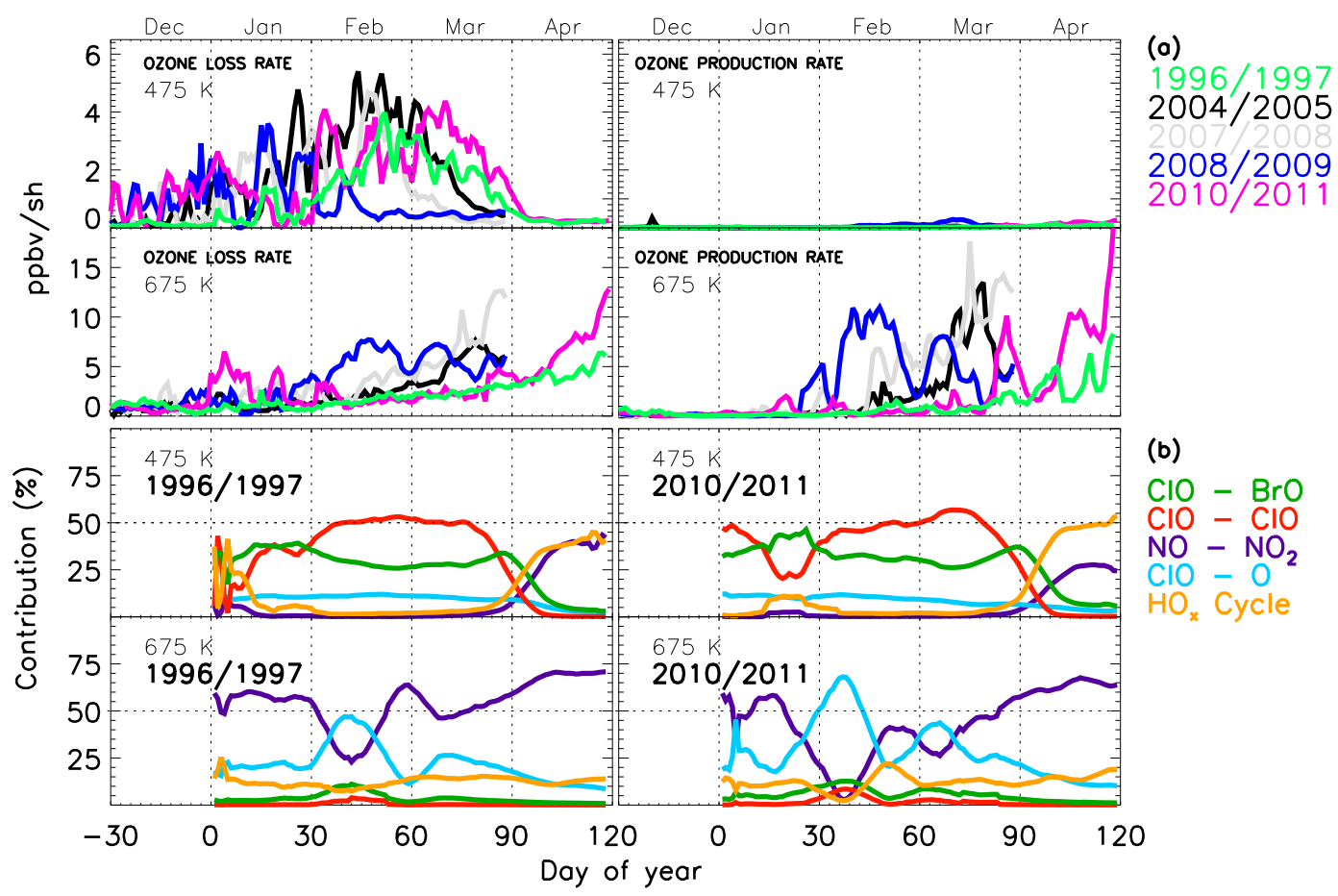

Fig. 6. (a) Vortex-averaged instantaneous ozone loss rates (left panel) and production rates (right panel) simulated by Mimosa-Chim at $475 \mathrm{~K}$ and $675 \mathrm{~K}$ for the Arctic winter 1996/1997 (light green) and 2010/2011 (magenta) compared to those of 2004/2005 (black), 2007/2008 (grey), and 2008/2009 (blue). (b) Temporal evolution of the vortex-averaged contribution of the $\mathrm{ClO}-\mathrm{BrO}$ (dark green), $\mathrm{ClO}-\mathrm{ClO}$ (red), $\mathrm{NO}-\mathrm{NO} 2$ (violet), ClO-O (light blue), and $\mathrm{HO}_{\mathrm{x}}$ (yellow) chemical cycles during the Arctic winter 1996/1997 (left panel) and 2010/2011 (right panel) at $475 \mathrm{~K}$ and $675 \mathrm{~K}$. The dotted horizontal lines represent $50 \%$ of contribution and the vertical dotted lines mark the approximate boundaries of each month.

duration of the contributions of these cycles and associated ozone loss in the middle stratosphere primarily depend on the available oxygen atoms in this altitude region.

Note that the loss of $\mathrm{NO}_{\mathrm{x}}$ happens through photodissociation and thus in the absence of solar radiation during the polar night, it is chemically long-lived. Therefore, its abundance in a particular winter is largely controlled by the prevailing meteorology. When the polar vortex is very strong, large scale diabatic descent in the polar vortex can bring considerable amounts of $\mathrm{NO}_{\mathrm{x}}$ from higher altitudes (Solomon et al., 1982). Strong descent of $\mathrm{NO}_{\mathrm{x}}$ was also observed during the reformation of polar vortex after its split or displacement due to a major sudden stratospheric warming (MW). As discussed above, since the $\mathrm{NO}_{\mathrm{x}}$ catalysed chemistry is very important for the ozone loss at higher altitudes, the winters with larger mesospheric descent during MWs and solar proton events merit a special mention. For instance: studies report large scale $\mathrm{NO}_{\mathrm{x}}$-rich airmass descent during $\mathrm{MW}$ of the Arctic winter 2003/2004 and 2005/2006 (Randall et al., 2009), although the enhancement of stratospheric $\mathrm{NO}_{\mathrm{x}}$ in 2003/2004 was connected to solar proton events and associated excess production in the mesosphere (Vogel et al., 2008). Nevertheless, both of these winters were prone to additional ozone loss in the middle and upper stratosphere due to higher $\mathrm{NO}_{\mathrm{x}}$ abundances as reported by Vogel et al. (2008) and Kuttippurath et al. (2010b). It has to be kept in mind that there were no MWs and large $\mathrm{NO}_{\mathrm{x}}$ influx from the mesosphere in 1996/1997 and 2010/2011, and the contribution of $\mathrm{NO}_{\mathrm{x}}$ is discussed with respect to the amount of $\mathrm{NO}_{\mathrm{x}}$ present in $2010 / 2011$ in comparison to that of $1996 / 1997$ only. Therefore, the interannual variability of $\mathrm{NO}_{\mathrm{x}}$ (and thus, the $\mathrm{NO}_{\mathrm{x}}$ driven ozone loss) in the stratosphere depends on the dynamics of each winter.

\subsection{Partial column ozone loss}

To get a complete overview of the ozone loss, we have computed the partial column ozone loss in two potential temperature ranges, $350-850 \mathrm{~K}$ and $350-550 \mathrm{~K}$, from the MLS measurements inside the vortex and the corresponding MimosaChim simulations (shown in Figs. 4 and 5). In 1996/1997, the Mimosa-Chim simulated partial column ozone loss at the UARS MLS sampling points over $350-550 \mathrm{~K}$ reaches $7 \mathrm{DU}$ (Dobson Unit), $17 \mathrm{DU}$, and 44 DU in late January, late February and late April, respectively. The accumulated ozone loss from the model over $350-850 \mathrm{~K}$ by late April shows 62 DU. Identical values are also estimated from the UARS MLS measurements, about 43 DU over $350-550 \mathrm{~K}$ and $61 \mathrm{DU}$ over $350-850 \mathrm{~K}$ by late April. These estimations 


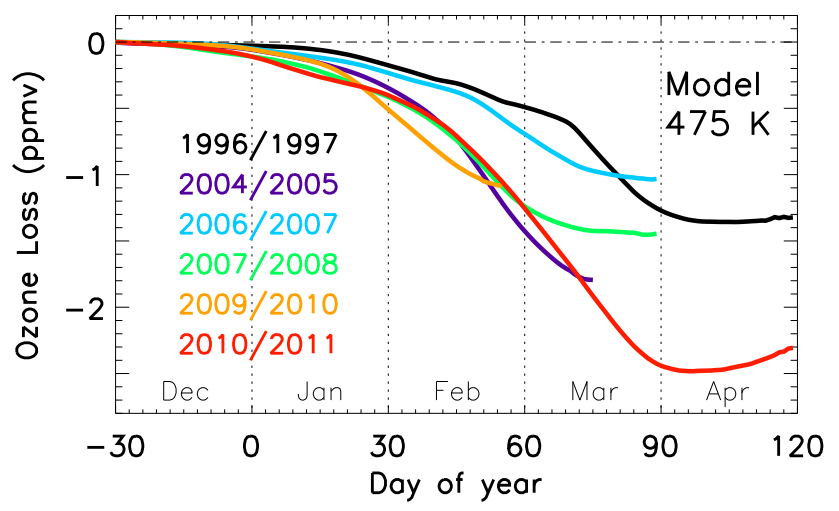

Fig. 7. Vortex-averaged ozone loss simulated by Mimosa-Chim for the Arctic winters 1996/1997 (black), 2004/2005 (violet), 2006/2007 (blue), 2007/2008 (green), 2009/2010 (yellow), and $2010 / 2011$ (red) at $475 \mathrm{~K}$. The dotted vertical lines mark approximate boundaries of each month and the dash-dotted horizontal line is 0 ppmv.

are close to the findings of Tilmes et al. (2006) and Harris et al. (2010), who report about $61 \pm 20 \mathrm{DU}$ from satellite and $50 \pm 20 \mathrm{DU}$ from ozonesonde measurements, respectively, over $380-550 \mathrm{~K}$. The total column ozone loss simulated with REPROBUS, about 50-60 DU (Lefèvre et al., 1998), is also comparable to our estimations. However, these estimations are significantly smaller than the total column ozone loss computed from ozonesonde observations by Knudsen et al. (1998), and Terao et al. (2002), of about 79-96 DU. This offset could be due to the differences in the model simulations, vortex edge criterion, ozone loss estimation method and data used for the loss computations in the respective studies.

In 2010/2011, the partial column ozone loss simulated by Mimosa-Chim at the Aura MLS footprints reaches about $6 \mathrm{DU}, 20 \mathrm{DU}, 62 \mathrm{DU}$, and $112 \mathrm{DU}$ by the end of each month from December through March, and 148 DU in mid-April over $350-550 \mathrm{~K}$. The maximum ozone loss estimated for the $350-850 \mathrm{~K}$ altitude range is slightly higher, about $160 \mathrm{DU}$ in mid-April, consistent with the loss simulated above $550 \mathrm{~K}$. The Aura MLS observations show an analogous progression of ozone depletion with time for both column ranges, but the maximum loss is slightly lower than the simulated one, about $115 \mathrm{DU}$ at $350-550 \mathrm{~K}$ and $131 \mathrm{DU}$ at $350-850 \mathrm{~K}$. These differences are consistent with the bias found between the measured and modeled $\mathrm{ClO}$ and $\mathrm{O}_{3}$. Nonetheless, these column ozone loss estimations are in good agreement with those estimated by Manney et al. (2011) from the Ozone Monitoring Instrument measurements on 26 March 2011 ( 140 DU total column loss) and by Sinnhuber et al. (2011) from the MIPAS observations by late March ( $\sim 120$ DU at $380-550 \mathrm{~K})$. The total column ozone loss calculated from the Multi-sensor Reanalysis by Balis et al. (2011) is about $95 \pm 8$ DU (personal communication) and is comparable to our estimations. The slight differences between various ozone loss estimates
Table 1. Vortex-averaged ( $\geq 65^{\circ}$, Equivalent Latitude) partial column ozone loss (DU) estimated over $350-850 \mathrm{~K}$ and $350-550 \mathrm{~K}$ from the MLS sampling inside the vortex and corresponding Mimosa-Chim simulations. Here the winter 1996/1997 is 1997 and the same nomenclature procedure is also used for the other winters. The calculations for the moderately cold winter 2010 is done from 1 December to 28 February. The maximum loss is found (shown below) around late/mid-March in 2005, 2007, and 2008 and around late/mid-April in 1997 and 2011.

\begin{tabular}{lrrrrrr}
\hline $350-850 \mathrm{~K}$ & 1997 & 2005 & 2007 & 2008 & 2010 & 2011 \\
\hline Mimosa-Chim & 61 & 109 & 80 & 98 & 79 & 160 \\
MLS & 60 & 115 & 84 & 112 & 60 & 130 \\
\hline $350-550 \mathrm{~K}$ & & & & & & \\
\hline Mimosa-Chim & 42 & 91 & 57 & 80 & 55 & 140 \\
MLS & 41 & 81 & 62 & 90 & 42 & 115 \\
\hline
\end{tabular}

can be due to the reasons discussed above (for the winter 1996/1997). However, the difference with Balis et al. (2011) could be due to the differences in vortex area calculations, as they use a vortex edge criterion of $70^{\circ} \mathrm{N}$ Equivalent Latitude at $475 \mathrm{~K}$, but we consider the vortex criterion at each altitude. This is particularly important as they use total column ozone data. In addition, their passive tracer simulation is slightly different from that shown in other studies. Note also that model differences or inaccuracies in passive tracer calculations can significantly affect the loss values. For instance: ozone loss calculations based on a pseudo-tracer, in which only chlorine-activating heterogeneous reactions are turned off (Balis et al., 2011; Singleton et al., 2005), yield about $10-25 \%$ lower loss than that estimated in this study.

\subsection{Comparison with other Arctic winters}

Though ozone loss in the Arctic has been observed and estimated since 1989, there were only a few cold winters showing large ozone loss in the last two decades (e.g. Manney et al., 2011; Sonkaew et al., 2011; Kuttippurath et al., 2010b; WMO, 2007; Grooß et al., 2005; Goutail et al., 2005; Rex et al., 2004). A majority of the Arctic winters were warm (e.g. 2000/2001, 2003/2004, 2005/2006 and 2008/2009) or moderately cold (e.g. 1991/1992, 1993/1994, 1997/1998, 2006/2007, and 2007/2008), and therefore, the ozone loss estimated from ground-based UV-visible total ozone measurements showed a loss of about 25-30 DU and 60 DU, respectively (WMO, 2011). The winters 1994/1995, 1995/1996, $1999 / 2000$, and 2004/2005 were very cold with significant ozone loss of $>80-90$ DU (Kuttippurath et al., 2010b; Goutail et al., 2005). Note that a similar ozone depletion computation over $380-550 \mathrm{~K}$ from ozonesonde and satellite measurements is also available for each winter (WMO, 2011; Harris et al., 2010; Tilmes et al., 2006; Andersen and Knudsen, 2002). Table 1 shows the partial column ozone loss over 
two different altitude bounds for the recent cold/moderately cold Arctic winters. Compared to the other Arctic winters, the loss in 1996/1997 is on the scale of a moderately cold winter, i.e. 60-61 DU over 350-850 K. However, the loss estimated for $2010 / 2011,130-160$ DU over $350-850 \mathrm{~K}$, is undoubtedly the largest among the Arctic winters, as the previous maximum of 109-115 DU was in 2004/2005 (WMO, 2011; Kuttippurath et al., 2010b). Figure 7 also shows that the loss in 1996/1997 is moderate (1.2 ppmv) and the loss in 2010/2011 is the largest ( $2.4 \mathrm{ppmv}$ ) as compared to other winters. The ozone loss in 2004/2005 is somewhat larger than that of 2010/2011 in February-March, but the additional loss of $\sim 0.8$ ppmv thereafter, in mid-March to midApril 2011, is exceptional. Thus, our analyses confirm the results presented by Manney et al. (2011), who discuss ozone loss during several cold Arctic winters using ozone loss profiles.

\section{Comparison with the Antarctic scenario}

Since the ozone loss in the Arctic winter 2010/2011 is unprecedented as analysed in this and previous studies (Manney et al., 2011; Sinnhuber et al., 2011), we compare the results with the Antarctic ozone loss. Some additional model runs are performed for a few Antarctic winters and are compared to the Aura MLS observations. Though the main ozone loss processes are alike, the meteorology is entirely different in the two polar regions, giving rise to the difference between the ozone loss observed in the respective polar regions (Solomon et al., 2007; WMO, 2007). On average, our analyses for various winters in 2004-2010 show that peak ozone loss ( $>2$ ppmv) in the Antarctic stratosphere occurs over a broader altitude range of 350-650 K and usually shows its maximum in the late September and early October period. The peak ozone loss altitudes hardly change, but the maximum loss usually varies between $2.5 \mathrm{ppmv}$ and $3.5 \mathrm{ppmv}$, depending on the temperature history of each winter. The colder Antarctic winters such as 2006 show a peak loss of about 3.5 ppmv, while the warmer winters, like 2004 and 2009, exhibit a peak loss of about 2.5 ppmv over $450-550 \mathrm{~K}$. In addition, the total column ozone loss in the Antarctic winters usually shows about $130-150$ DU in the warmer winters and about 160-180 DU in the colder winters (Kuttippurath et al., 2010a). It appears that the maximum partial column ozone loss estimated for the Arctic winter 2010/2011 in this study is close to the loss computed for the early years of Antarctic ozone depletion (1985-1991) (Manney et al., 2011; WMO, 2007) and the relatively warmer Antarctic winters (e.g. 2002, 2004, and 2009) (WMO, 2011, 2007; Manney et al., 2011; Kuttippurath et al., 2010a).

Figure 8 illustrates the vortex-averaged $\mathrm{ClO}$ and ozone loss estimated in the Arctic winter 2010/2011 and the mean vortex-averaged ozone loss estimated for the seven Antarctic winters: 2004-2010. We use the same model Mimosa-

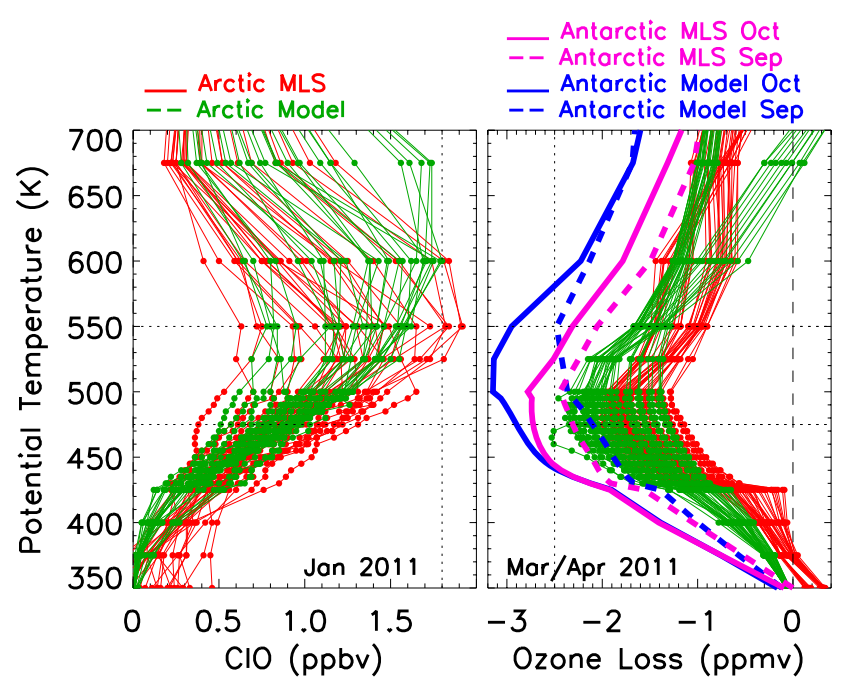

Fig. 8. $\mathrm{ClO}$ (left) and ozone loss (right) profiles inside the vortex from Mimosa-Chim (green) and MLS (red) in the Arctic winter 2010/2011, and the mean September and October ozone loss profiles in the Antarctic vortex averaged for seven winters (20042010). The dotted vertical line is $1.8 \mathrm{ppbv}$ of $\mathrm{ClO}$ or $2.5 \mathrm{ppmv}$ of ozone loss. The dashed vertical line is 0 ppmv. The dotted horizontal lines are $475 \mathrm{~K}$ and $550 \mathrm{~K}$.

Chim and model set-up (input data, chemistry and dynamics), Aura MLS measurements, and the passive method for the ozone loss calculations in the Antarctic to make a fair comparison with those in the Arctic. Note that the Antarctic measurements shown are the Aura MLS $\mathrm{O}_{3}$ v2.2, but the Arctic observations are v3.3. However, the difference between the vortex-averaged $\mathrm{O}_{3}$ from v2.2 and v3.3 is negligibly small and thus, we can robustly compare these values directly. The ozone loss estimated in these Antarctic winters is about 2.5-3.2 ppmv in the model and 2.4-2.8 ppmv in Aura MLS. The ozone loss estimated in March/April of the Arctic winter 2010/2011 is comparable to that of the September average in the Antarctic, as already shown by Manney et al. (2011). Nevertheless, the Arctic ozone loss is marginally smaller than that of the October average that includes three relatively warm (2004, 2009 and 2010) and two very cold (2006 and 2008) Antarctic winters. The altitudes of maximum ozone loss of the 2010/2011 Arctic winter, 425-575 K, are also identical to those of the Antarctic winters. Therefore, in addition to the column ozone, the ozone loss profiles in the Arctic winter 2010/2011 also show ozone loss features matching those found in the Antarctic stratosphere. The model simulates relatively lower $\mathrm{O}_{3}$ than MLS for most Antarctic winters and thus, modeled ozone loss (i.e. model $\mathrm{O}_{3}$ - model tracer) is larger than the loss estimated with the MLS measurements (i.e. MLS $\mathrm{O}_{3}$ - model tracer).

In most Arctic winters the peak ozone loss is confined to the lower stratosphere centered around $450 \mathrm{~K}$ (e.g. Manney et al., 2011, 2003; Kuttippurath et al., 2010b; Rex et al., 2004). 
The loss above $550 \mathrm{~K}$ contributes about $19 \pm 7 \mathrm{DU}$ to the total column loss, which is mainly driven by $\mathrm{NO}_{\mathrm{x}}$ catalyzed chemistry in the middle stratosphere (Kuttippurath et al., 2010b). On the other hand, as shown by the ozone loss profiles, ozone loss in the Antarctic stratosphere takes place over a broad altitude range centered around $550 \mathrm{~K}$, and thus nearly half of the loss occurs above this isentropic level. Therefore, the Antarctic partial column (380-550 K) ozone loss (around $130 \mathrm{DU}$ ) computed by Tilmes et al. (2006) is not directly comparable to the partial column ozone loss estimated here for the Arctic winter 2010/2011. In addition, the sparse sampling of the Halogen Occultation Experiment in the southern polar vortex region, which does not always cover the maximum ozone loss period of the Antarctic, makes the comparison more difficult.

\section{Conclusions}

A comprehensive analysis of the Arctic winters 1996/1997 and 2010/2011 is presented with respect to the dynamical and chemical evolution of the winters. Both winters show a prolonged stable vortex from December to late April. However, the winter 1996/1997 was moderately cold during December-February and thus, occasional chlorine activation led to a moderate ozone loss of about 1.2 ppmv around 475$550 \mathrm{~K}$ or $61 \mathrm{DU}$ over $350-850 \mathrm{~K}$ by late March-late April. In contrast, the Arctic winter 2010/2011 experienced the largest area and longest period ever of chlorine activation, with $\mathrm{ClO}$ values up to $1.8 \mathrm{ppbv}$ around $450-550 \mathrm{~K}$, which translated to the record ozone loss of around $2.4 \mathrm{ppmv}$ at the same altitudes in late-March/mid-April. The partial column estimates over $350-850 \mathrm{~K}$ also show a correspondingly massive loss of about 130-160 DU in mid-April. The simulated ozone loss rates show large values of 2-4 $\mathrm{ppbv} \mathrm{sh}^{-1}$ in March-early April at $475 \mathrm{~K}$, which are uncommon in the Arctic at this time of the winter. In tune with these ozone loss features, the $\mathrm{ClO}-\mathrm{ClO}$ and $\mathrm{ClO}-\mathrm{BrO}$ cycles show increasingly larger values ( $\sim 30-55 \%$ and $30-35 \%$, respectively) in late FebruaryMarch, as does the $\mathrm{HO}_{\mathrm{x}}$ cycle in April (about 30-50\%) in the lower stratosphere, at $475 \mathrm{~K}$. Additionally, significant ozone loss of about $0.7-1.2$ ppmv is also computed at $550-700 \mathrm{~K}$ in March-April 2011. As expected, the $\mathrm{NO}_{\mathrm{x}}$ cycle dominates the ozone destruction processes in the middle stratosphere, with a contribution of around $30-70 \%$ at $675 \mathrm{~K}$.

The ozone loss in the Arctic winter 2010/2011 is close to those estimated in the Antarctic winters, as assessed in this study and already shown by Manney et al. (2011). However, it has to be kept in mind that the ozone loss values in the Arctic winter 2010/2011 are comparable to those of the relatively warm Antarctic winters only, though September averages of the cold Antarctic winters also show similar magnitude of ozone loss. This is also applicable to total column ozone loss analyses as they show loss ranges (130-140 DU) equivalent to those of the warm Antarctic winters (e.g. 2004 and 2010) and the early years of the Antarctic ozone depletion (19851991), as discussed in Sect. 4. The atypically prolonged chlorine activation and large denitrification triggered this high ozone loss of 2.4 ppmv or 130-160 DU in 2010/2011. Furthermore, large loss (1.5 ppmv) over a broader altitude range $(400-600 \mathrm{~K})$ similar to that of the Antarctic is observed for the first time in the 2010/2011 Arctic winter. Nevertheless, since the halogens are decreasing slowly, the ozone loss in the polar stratosphere is expected to decrease even in cold winters. Yet, as discussed in Sinnhuber et al. (2011), with the predicted rate of stratospheric cooling in a climate changing world, the expected reduction in halogens may not help to cut down the ozone loss rates in very cold winters in the next decade. Therefore, cold winters of this kind with a similar range of ozone loss can be expected in the future (Manney et al., 2011; Sinnhuber et al., 2011).

\section{Supplementary material related to this article is available online at: http://www.atmos-chem-phys.net/12/ 7073/2012/acp-12-7073-2012-supplement.pdf.}

Acknowledgements. The ECMWF data are taken from the NADIR/NILU data base and are greatly acknowledged. J. K. thanks Cathy Boonne, IPSL, Paris for the REPROBUS model code for the simulations and Slimane Bekki and Marion Marchand for their support during this study. Participation of Jayanarayanan Kuttippurath and Franck Lefèvre in this work was supported by the European Commission as a part of the FP7 RECONCILE project under the Grant number: RECONCILE-226365-FP7-ENV-2008-1. Work at the Jet Propulsion Laboratory, California Institute of Technology, was done under contract to NASA.

Edited by: W. Lahoz

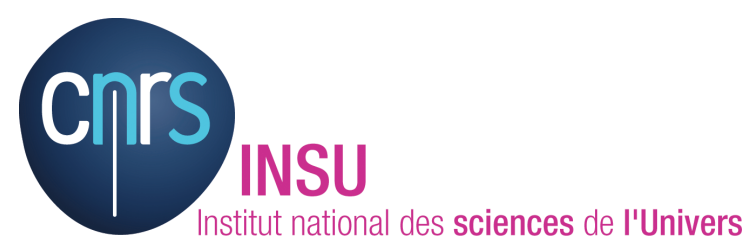

The publication of this article is financed by CNRS-INSU.

\section{References}

Andersen, S. B. and Knudsen, B. M.: The influence of vortex ozone depletion on Arctic ozone trends, Geophys. Res. Lett., 29, 2013, doi:10.1029/2001GL014595, 2002.

Balis, D., Isaksen, I. S. A., Zerefos, C., Zyrichidou, I., Eleftheratos, K., Tourpali, K., Bojkov, R., Rognerud, B., Stordal, F., Søvde, O. A., and Orsolini, Y.: Observed and Modelled record ozone decline over the Arctic during winter/spring 2011, Geophys. Res. Lett., 38, L23801, doi:10.1029/2011GL049259, 2011. 
Burkholder, J. B., Orlando, J. J., and Howard, C. J.: Ultraviolet absorption cross-sections of $\mathrm{Cl}_{2} \mathrm{O}_{2}$ between 210 and $410 \mathrm{~nm}$, J. Phys. Chem., 94, 687-695, 1990.

Butz, A., Bösch, H., Camy-Peyret, C., Dorf, M., Engel, A., Payan, S., and Pfeilsticker, K.: Observational constraints on the kinetics of the $\mathrm{ClO}-\mathrm{BrO}$ and $\mathrm{ClO}-\mathrm{ClO}$ ozone loss cycles in the Arctic winter stratosphere, Geophys. Res. Lett., 34, L05801, doi:10.1029/2006GL028718, 2007.

Coy, L., Nash, E. R., and Newman, P. A.: Meteorology of the polar vortex: Spring 1997, Geophys. Res. Lett., 24, 2693-2696, 1997.

Froidevaux, L., Jiang, Y. B., Lambert, A., Livesey, N. J., Read, W. G., Waters, J. W., Browell, E. V., Hair, J. W., Avery, M. A., McGee, T. J., Twigg, L. W., Sumnicht, G. K., Jucks, K. W., Margitan, J. J., Sen, B., Stachnik, R. A., Toon, G. C., Bernath, P. F., Boone, C. D., Walker, K. A., Filipiak, M. J., Harwood, R. S., Fuller, R. A., Manney, G. L., Schwartz, M. J., Daffer, W. H., Drouin, B. J., Cofield, R. E., Cuddy, D. T., Jarnot, R. F., Knosp, B. W., Perun, V. S., Snyder, W. V., Stek, P. C., Thurstans, R. P., Wagner, P. A.: Validation of Aura Microwave Limb Sounder stratospheric ozone measurements, J. Geophys. Res., 113, D15S20, doi:10.1029/2007JD008771, 2008.

Goutail, F., Pommereau, J.-P., Lefèvre, F., van Roozendael, M., Andersen, S. B., Kåstad Høiskar, B.-A., Dorokhov, V., Kyrö, E., Chipperfield, M. P., and Feng, W.: Early unusual ozone loss during the Arctic winter 2002/2003 compared to other winters, Atmos. Chem. Phys., 5, 665-677, doi:10.5194/acp-5-665-2005, 2005.

Grooß, J.-U., Konopka, P., and Müller, R.: Ozone chemistry during the 2002 Antarctic vortex split, J. Atmos. Sci., 62, 860-870, 2005.

Hanson, D. and Mauersberger, K.: Laboratory studies of the nitric acid trihydrate: implications for the south polar stratosphere, Geophys. Res. Lett., 15, 855-858, 1998.

Hanson, G. and Chipperfield, M.: Ozone loss at the edge of the polar vortex, J. Geophys. Res., 104, 1837-1845, 1999.

Harris, N. R. P., Lehmann, R., Rex, M., and von der Gathen, P.: A closer look at Arctic ozone loss and polar stratospheric clouds, Atmos. Chem. Phys., 10, 8499-8510, doi:10.5194/acp-10-84992010, 2010.

Hurwitz, M. M., Newman, P. A., and Garfinkel, C. I.: The Arctic vortex in March 2011: a dynamical perspective, Atmos. Chem. Phys., 11, 11447-11453, doi:10.5194/acp-11-11447-2011, 2011.

Kleinböhl, A., Bremer, H., Küllmann, H., Kuttippurath, J., Browell, E. V., Canty, T., Salawitch, R. J., Toon, G. C., and Notholt, J.: Denitrification in the Arctic mid-winter 2004/2005 observed by airborne submillimeter radiometry, Geophys. Res. Lett., 32, L19811, doi:10.1029/2005GL023408, 2005.

Knudsen, B. M., Larsen, N., Mikkelsen, I. S., Morcrette, J.-J., Braathen, G. O., Kyro, E., Fast, H., Gernandt, H., Kanzawa, H., Nakane, H., Dorokhov, V., Yushkov, V., Hansen, G., Gil, M., and Shearman, R. J.: Ozone depletion in and below the Arctic vortex for 1997, Geophys. Res. Lett., 25, 627-630, 1998.

Kondo, Y., H. Irie, M. Koike, and G. E. Bodeker: Denitrification and nitrification in the Arctic stratosphere during the winter of 1996-1997, Geophys. Res. Lett., 27, 337-340, doi:10.1029/1999GL011081, 2000.

Kuttippurath, J., Goutail, F., Pommereau, J.-P., Lefèvre, F., Roscoe, H. K., Pazmiño, A., Feng, W., Chipperfield, M. P., and GodinBeekmann, S.: Estimation of Antarctic ozone loss from ground- based total column measurements, Atmos. Chem. Phys., 10, 6569-6581, doi:10.5194/acp-10-6569-2010, 2010a.

Kuttippurath, J., Godin-Beekmann, S., Lefèvre, F., and Goutail, F.: Spatial, temporal, and vertical variability of polar stratospheric ozone loss in the Arctic winters 2004/2005-2009/2010, Atmos. Chem. Phys., 10, 9915-9930, doi:10.5194/acp-10-9915-2010, 2010b.

Lefèvre F., Figarol, F., Carslaw, K. S., and Peter, T.: The 1997 Arctic ozone depletion quantified from three-dimensional model simulations, Geophys. Res. Lett., 25, 2425-2428, 1998.

Livesey, N. J., Read, W. G., Froidevaux, L., Waters, J. W., Santee, M. L., Pumphrey, H. C., Wu, D. L., Shippony, Z., and Jarnot, R. F.: The UARS Microwave Limb Sounder version 5 data set: Theory, characterization, and validation, J. Geophys. Res., 108, 4378, doi:10.1029/2002JD002273, 2003.

Livesey, N. J., Read, W. G., Froidevaux, L., Lambert, A., Manney, G. L., Pumphrey, H. C., Santee, M. L., Schwartz, M. J., Wang, S., Cofeld, R. E., Cuddy, D. T., Fuller, Jarnot, R. F., Jiang, J. H., Knosp, B. W., Stek, P. C., Wagner, P. A., and Wu, D. L.: Earth Observing System (EOS) Aura Microwave Limb Sounder (MLS) Version 3.3 Level 2 data quality and description document, JPL D-33509, Jet Propulsion Laboratory California Institute of Technology, Pasadena, California, USA, 91109-8099, 2011.

Manney, G. L., Froidevaux, L., Santee, M. L., Zurek, R. W., and Waters, J. W.: MLS observations of Arctic ozone loss in 19961997, Geophys. Res. Lett., 24, 2697-2700, 1997.

Manney, G. L., Froidevaux, L., Santee, M., Livesey, N., Sabutis, J., and Waters, J.: Variability of ozone loss during Arctic winter (1991-2000) estimated from UARS Microwave Limb Sounder measurements, J. Geophys. Res., 108, 4149, doi:10.1029/2002JD002634, 2003.

Manney, G. L., Santee, M. L., Rex, M., Livesey, N. J., Pitts, M. C., Veefkind, P., Nash, E. R., Wohltmann, I., Lehmann, R., Froidevaux, L., Poole, L. R., Schoeberl, M. R., Haffner, D. P., Davies, J., Dorokhov, V., Gernandt, H., Johnson, B., Kivi, R., Kyro, E., Larsen, N., Levelt, P. F., Makshtas, A., McElroy, C. T., Nakajima, H., Parrondo, M. C., Tarasick, D. W., von der Gathen, P., Walker, K. A., and Zinoviev, N. S.: Unprecedented Arctic ozone loss in 2011, Nature, 478, 469-475, doi:10.1038/nature10556, 2011.

Papanastasiou, D. K., Papadimitriou, V. C., Fahey, D. W., and Burkholder, J. B.: UV Absorption Spectrum of the ClO Dimer $\left(\mathrm{Cl}_{2} \mathrm{O}_{2}\right)$ between 200 and $420 \mathrm{~nm}$, J. Phys. Chem. A, 113, 13711-13726, 2009.

Pitts, M. C., Thomason, L. W., Poole, L. R., and Winker, D. M.: Characterization of Polar Stratospheric Clouds with spaceborne lidar: CALIPSO and the 2006 Antarctic season, Atmos. Chem. Phys., 7, 5207-5228, doi:10.5194/acp-7-5207-2007, 2007.

Randall, C. E., Harvey, V. L., Siskind, D. E., France, J., Bernath, P. F., Boone, C. D., and Walker, K. A.: $\mathrm{NO}_{\mathrm{x}}$ descent in the Arctic middle atmosphere in early 2009, Geophys. Res. Lett., 36, L18811, doi:10.1029/2009GL039706, 2009.

Rex, M., Salawitch, R. J., von der Gathen, P., Harris, N. R. P., Chipperfield, M. P., and Naujokat, B.: Arctic ozone loss and climate change, Geophys. Res. Lett., 31, L04116, doi:10.1029/2003GL018844, 2004.

Sander, S., Friedl, R., Ravishankara, A., Golden, D., Kolb, C., Kurylo, M., Molina, M., Moortgat, G., Keller-Rudek, H., Finlayson-Pitts, B., Wine, P., Huie, R., and Orkin, V.: Chemical Kinetics and Photochemical Data for Use in Atmospheric Stud- 
ies (Evaluation Number 15), JPL Publication: 06-2, 2006.

Santee, M. L., Manney, G. L., Froidevaux, L., Zurek, R. W., and Waters, J. W.: MLS observations of $\mathrm{ClO}$ and $\mathrm{HNO}_{3}$ in the 1996-97 Arctic polar vortex, Geophys. Res. Lett., 24, 2713-2716, 1997.

Santee, M. L., Manney, G. L., Froidevaux, L., Read, W. G., and Waters, J. W.: Six years of UARS Microwave Limb Sounder $\mathrm{HNO}_{3}$ observations: Seasonal, interhemispheric, and interannual variations in the lower stratosphere, J. Geophys. Res., 104, 82258246, 1999.

Santee, M. L., Lambert, A., Read, W. G., Livesey, N. J., Manney, G. L., Cofield, R. E., Cuddy, D. T., Daffer, W. H., Drouin, B. J., Froidevaux, L., Fuller, R. A., Jarnot, R. F., Knosp, B. W., Perun, V. S., Snyder, W. V., Stek, P. C., Thurstans, R. P., Wagner, P. A., Waters, J. W., Connor, B., Urban, J., Murtagh, D., Ricaud, P., Barrett, B., Kleinböhl, A., Kuttippurath, J., Küllmann, H., von Hobe, M., Toon, G. C., and Stachnik, R. A.: Validation of the Aura Microwave Limb Sounder ClO measurements, J. Geophys. Res., 113, D15S22, doi:10.1029/2007JD008762, 2008.

Shine, K. P.: The middle atmosphere in the absence of dynamical heat fluxes, Q. J. Roy. Meteorol. Soc., 113, 603-633, 1987.

Singleton, C. S., Randall, C. E., Chipperfield, M. P., Davies, S., Feng, W., Bevilacqua, R. M., Hoppel, K. W., Fromm, M. D., Manney, G. L., and Harvey, V. L.: 2002-2003 Arctic ozone loss deduced from POAM III satellite observations and the SLIMCAT chemical transport model, Atmos. Chem. Phys., 5, 597609, doi:10.5194/acp-5-597-2005, 2005.

Sinnhuber, B.-M., Stiller, G. P., Ruhnke, R., von Clarmann, T., Kellmann, S., and Aschmann, J.: Arctic winter 2010/2011 at the brink of an ozone hole, Geophys. Res. Lett., 38, L24814, doi:10.1029/2011GL049784, 2011.

Solomon, S., Crutzen, P. J., and Roble, R. G.: Photochemical coupling between the thermosphere and the lower atmosphere: 1 . Odd nitrogen from 50 to $120 \mathrm{~km}$, J. Geophys. Res., 87, 72067220, 1982.

Solomon, S., Portmann, R. W., and Thompson, D. W. J.: Contrasts between Antarctic and Arctic ozone depletion, P. Natl. Acad. Sci. USA, 104, 445-449, 2007.

Sonkaew, T., von Savigny, C., Eichmann, K.-U., Weber, M., Rozanov, A., Bovensmann, H., and Burrows, J. P.: Chemical ozone loss in Arctic and Antarctic polar winter/spring season derived from SCIAMACHY limb measurements 2002-2009, Atmos. Chem. Phys. Discuss., 11, 6555-6599, doi:10.5194/acpd11-6555-2011, 2011.
Stimpfle, R. M., Wilmouth, D. M., Salawitch, R. J., and Anderson, J. G.: First measurements of $\mathrm{ClOOCl}$ in the stratosphere: the coupling of $\mathrm{ClOOCl}$ and $\mathrm{ClO}$ in the Arctic polar vortex, J. Geophys. Res., 109, D03301, doi:10.1029/2003JD003811, 2004

Terao, Y., Sasano, Y., Nakajima, H., Tanaka, H., and Yasunari, T.: Stratospheric ozone loss in the 1996/1997 Arctic winter: Evaluation based on multiple trajectory analysis for doublesounded air parcels by ILAS, J. Geophys. Res., 107, 8210, doi:10.1029/2001JD000615, 2002.

Tilmes, S., Müller, R., Engel, A., Rex, M., and Russell III, J.: Chemical ozone loss in the Arctic and Antarctic stratosphere between 1992 and 2005, Geophys. Res. Lett., 33, L20812, doi:10.1029/2006GL026925, 2006.

Tripathi, O. P., Godin-Beekmann, S., Lefèvre, F., Marchand, M., Pazmiño, A., Hauchecorne, A., Goutail, F., Schlager, H., Volk, C. M., Johnson, B., Konig-Langlo, G., Balestri, S., Stroh, F., Bui, T. P., Jost, H. J., Deshler, T., and von der Gathen, P.: High resolution simulation of recent Arctic and Antarctic stratospheric chemical ozone loss compared to observations, J. Atmos. Chem., 55, 205226, doi:10.1007/s10874-006-9028-8, 2006.

Vogel, B., Konopka, P., Grooß, J.-U., Müller, R., Funke, B., LópezPuertas, M., Reddmann, T., Stiller, G., von Clarmann, T., and Riese, M.: Model simulations of stratospheric ozone loss caused by enhanced mesospheric $\mathrm{NO}_{\mathrm{x}}$ during Arctic Winter 2003/2004, Atmos. Chem. Phys., 8, 5279-5293, doi:10.5194/acp-8-52792008, 2008.

Woyke, T., Müller, R., Stroh, F., McKenna, D. S., Engel, A., Margitan, J. J., Rex, M., and Carslaw, K. S.: A test of our understanding of the ozone chemistry in the Arctic polar vortex based on in situ measurements of $\mathrm{ClO}, \mathrm{BrO}$, and $\mathrm{O}_{3}$ in the 1994/1995 winter, J. Geophys. Res., 104, 18755-18768, 1999.

WMO (World Meteorological Organisation): Scientific assessment of ozone depletion: 2006, Global Ozone Research and Monitoring Project-Report No. 50, 572 pp., Geneva, Switzerland, 2007.

WMO (World Meteorological Organisation): Scientific assessment of ozone depletion: 2006, Global Ozone Research and Monitoring Project-Report No. 52, 516 pp., Geneva, Switzerland, 2011.

Woods, A.: Medium-Range Weather Prediction - the European Approach, Springer, ISBN 978-0387269283, 2006. 